\title{
BMJ Open Developing a systematic approach for Population-based Injury Severity Assessment (PISA): a million-person survey in rural Bangladesh
}

\author{
Olakunle Alonge, ${ }^{1}$ Priyanka Agrawal (D) , ${ }^{1}$ Khaula Khatlani, ${ }^{2}$ Saidur Mashreky (D) , ${ }^{3}$
} Dewan Emdadul Md Hoque, ${ }^{4}$ Adnan A Hyder ${ }^{5}$

To cite: Alonge 0, Agrawal P, Khatlani K, et al. Developing a systematic approach for Population-based Injury Severity Assessment (PISA): a million-person survey in rural Bangladesh. BMJ Open 2021;11:e042572. doi:10.1136/ bmjopen-2020-042572

- Prepublication history and supplemental material for this paper is available online. To view these files, please visit the journal online (http://dx.doi org/10.1136/bmjopen-2020042572).

Received 09 July 2020 Revised 04 April 2021 Accepted 16 April 2021
Check for updates

(C) Author(s) (or their employer(s)) 2021. Re-use permitted under CC BY-NC. No commercial re-use. See rights and permissions. Published by BMJ.

For numbered affiliations see end of article.

Correspondence to Dr Olakunle Alonge; oalonge1@jhu.edu

\section{ABSTRACT}

Introduction There is currently no defined method for assessing injury severity using population-based data, which limits our understanding of the burden of non-fatal injuries and community-based approaches for primary prevention of injuries. This study describes a systematic approach, Population-based Injury Severity Assessment (PISA) index, for assessing injury severity at the population level.

Methods Based on the WHO International Classification of Functionality conceptual model on health and disability, eight indicators for assessing injury severity were defined. The eight indicators assessed anatomical, physiological, postinjury immobility, hospitalisation, surgical treatment, disability, duration of assisted living and days lost from work or school. Using a large population-based survey conducted in 2013 including 1.16 million individuals from seven subdistricts of rural Bangladesh, information on the eight indicators were derived for all non-fatal injury events, and these were summarised into a single injury severity index using a principal component analysis (PCA). Principal component loadings derived from the PCA were used to predict the severity (low, moderate, high) of non-fatal injuries, and were applied to the fatal injury data to assess the criterion validity of the index. The determinants of nonfatal injury severity were determined using ordered logistic regression.

Results There were 119703 non-fatal injuries and $14 \%$ were classified as high severity based on the PISA index. The PISA index accurately predicted $82 \%$ of all fatal injuries as highly severe. Non-fatal injuries of high severity were frequent with unintentional poisoning $(57 \%)$ and violence $(35 \%)$. Injuries of high severity were commoner among males ( $0 \mathrm{R} 1.16,95 \% \mathrm{Cl} 1.12$ to 1.21 ), adults 65 years and older (OR $1.30,95 \% \mathrm{Cl} 1.23$ to 1.36 ), lower socioeconomic status and intentional injuries. Education was associated with reduced odds of high severe injuries.

Conclusion The PISA index provides a valid and systematic approach for assessing injury severity at the population level, and is relevant for improving the characterisation of the burden and epidemiology of injuries in non-health facility-based settings. Additional testing of the PISA index is needed to further establish its validity and reliability.
Strengths and limitations of this study

- The eight indicators defined for assessing injury severity in the Population-based Injury Severity Assessment (PISA) index are based on a robust conceptual model, the WHO International Classification of Functionality model on health and disability.

- The principal component analysis (PCA), used in summarising the eight indicators and predicting Injury Severity Scores, is based on non-parametric statistics and requires no assumption regarding the underlying distribution of the data and this confers a methodological advantage.

- The parameters from such PCA, for example, the principal component loadings and eigenvectors, are however complicated to explain and interprete on their own, except when applied as used in the PISA index.

- The use of a large sample-sized survey, including over a million population with more than 100000 injury outcomes, confers a significant advantage on the stability of the parameters and estimates derived from both the PCA and the multivariable logistics regression models used in assessing the determinants of injury severity.

- However, the information on the injury outcomes from the survey is subject to significant recall bias, with participants more likely to recall more severe injuries, and differential recall of the eight indicators assessed.

\section{INTRODUCTION}

Injuries are among the leading causes of death across all ages in low-income and middle-income countries (LMICs) and highincome countries (HICs). ${ }^{1}$ Injuries account for around $9 \%$ of all deaths globally and more than two-thirds are unintentional in nature. ${ }^{2}$ Road traffic injuries (RTI) are among the top causes of injury related disability adjusted life years in adolescents 10-24 years of age. ${ }^{3}$ For every fatal injury outcome that occurs in HICs like the USA, about 1000 non-fatal 
injuries present in emergency departments, and many more go unreported. ${ }^{4}$ The ratio of one fatal to 500 nonfatal injuries in LMICs is significant too. However, the ratio in LMIC may suggest an undercounting of injury outcomes broadly, and reflects the disparity in access to quality medical care when compared with the US ratio. ${ }^{5}$ Further, long-term disabilities that may occur as a sequelae to severe non-fatal injuries make the burden of non-fatal injuries even more remarkable when adequately measured. ${ }^{6}$

The lack of population-based data, especially in LMICs, has indeed contributed to the underestimation of the global burden of disease (GBD) for non-fatal injuries. ${ }^{7-9}$ Most injury events in LMICs do not present in health facilities. ${ }^{5}$ However, most GBD estimates for non-fatal injuries are derived from facility-based data; thus, significantly undercount non-fatal injury events. ${ }^{7-9}$ Similarly, indices and measures used to describe non-fatal injury severity have limited applicability as they are predominantly facility based, and are not applicable to injury events that occur outside of health facilities. ${ }^{1011}$ Methods for characterising injury severity for events captured in population-based data are lacking, and this inadequacy in assessing severity of non-fatal injuries further contributes to the underestimation of the burden of non-fatal injuries globally. ${ }^{12}$

Most facility-based injury severity indices use either anatomical or physiological indicators or both to categorise injury severity. The Injury Severity Score (ISS), developed mainly to assess RTIs is an anatomical scoring system, determines injury severity based on three most severely injured body parts, and has application in trauma centres and emergency departments to assist in triage, clinical management and evaluating outcomes. ${ }^{13}$ Trauma scoring systems, such as the Revised Trauma Score and the Glasgow Coma scale (GCS) solely rely on physiological data and provide assistance for initial triage in facility-based settings but do not accurately predict injury outcomes. ${ }^{13-15}$ Combinations of anatomical, physiological and demographic indicators such as the Trauma and Injury Severity Score (TRISS) and A Severity Characterisation of Trauma (ASCOT) have been used to characterise injury severity in trauma resuscitation centres, and are better at predicting mortality and morbidity in blunttrauma patients compared with other scores. ${ }^{16}$ However, both the TRISS and ASCOT lack a corollary that can be used to characterise injury severity in populationbased data. A clear lack of a population-based assessment has implications for primary prevention planning and resource allocation for injuries in community-based settings.

The goal of this paper is to construct a Populationbased Injury Severity Assessment (PISA) score, informed by existing injury severity indices, but adapted for population-based data and applied to a demographic and injury census conducted in rural Bangladesh in 2013. ${ }^{5}$ It is expected that this score will demonstrate a systematic approach for assessing injury severity at the population level, and contribute to improved characterisation of the burden and epidemiology of injuries.

\section{METHOD}

Data source, sample size and participants

Demographic and injury census

The population-based data for this study were sourced from a baseline census conducted between June and November 2013 as part of the Saving of Lives from Drowning project (SoLiD) in Bangladesh. ${ }^{5}$ The census covered all 270387 households and 1.16 million people from 451 villages in 51 unions (out of 83 unions) from seven rural sub-districts of the country (Matlab North, Matlab South, Daudkandi, Chandpur Sadar, Manohardi, Raiganj, and Sherpur). ${ }^{5}$ The census collected information on all non-fatal and fatal injuries for all individuals, over a 6-month and 1-year recall period, respectively. Demographic and socioeconomic characteristics were also collected for these individuals. ${ }^{5}$

During the census, an injury morbidity module was completed for all individuals reporting any non-fatal and fatal injuries to collect information on the external mechanisms of injuries, intent and body part affected by the injury event. ${ }^{5}$ It also collected information on characteristics and outcomes of all non-fatal injury events, including physiologic responses, disability and treatment outcomes. The injury morbidity module was adapted from the WHO Injury Surveillance Guidelines. ${ }^{17}$

An injury event was operationally defined as 'any household member who sought treatment or lost at least one working day or could not go to the school for at least 1 day in the last 6 months due to injury causes defined based on external causes in Chapter XIX, and the external causes of morbidity and mortality in Chapter XX, of the International Statistical Classification of Diseases and Related Health Problems, 10th edition, including: attempted suicide, transport injury, violence, fall, cut, burn, near drowning, unintentional poisoning, machine injury, electrocution, insect/animal injury, injury by blunt object and suffocation' ${ }^{18}$ Questions on the body part and function affected, loss of activities and participation, hospitalisation and treatment outcomes following an injury event were included to further assess the injury outcomes. These questions reflect the WHO International Classification of Functionality (ICF) index's notion of a continuum between health and disability, but operationalised with items that can be applied for an injury surveillance system captured at the population-level. ${ }^{519}$ The questionnaire, data collection procedure for the census along with the findings on the fatal and non-fatal injury outcomes are published elsewhere. $^{5}$

\section{Indicators and data analyses}

Defining indicators of injury severity

The development of our indicators was guided by the WHO ICF conceptual model on health and disability (figure 1). ${ }^{19}$ The WHO ICF model conceptualises that 


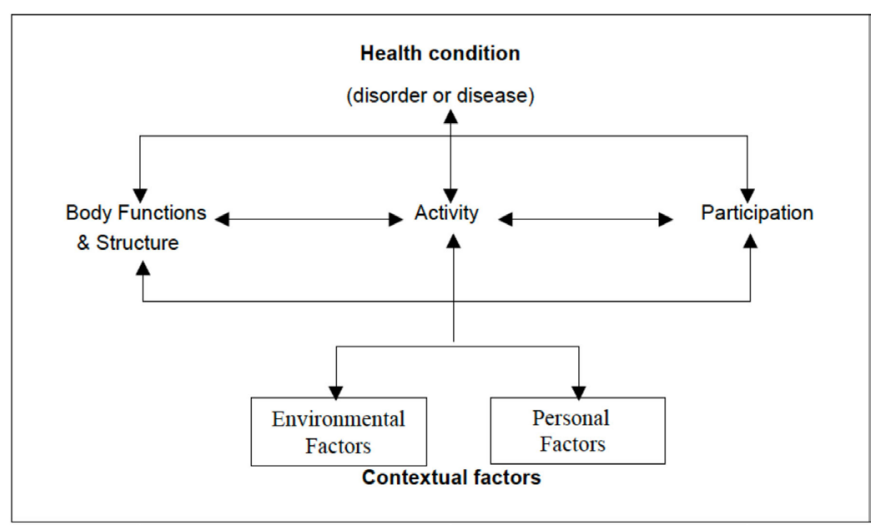

Figure 1 WHO ICF conceptual model on health and disability. ICF, International Classification of Functionality.

the continuum of health and disability for an individual could be primarily described by indices of body function and structure (physiological functions and anatomical parts of an individual), activity (execution of a task or action by an individual) and participation (involvement in life situation); and that these indices could be influenced by personal (eg, gender, age) and environmental factors (eg, socioeconomic factor, physical terrain).

To identify various published measures of injury severity that reflect this model, a literature review was conducted in PubMed and Google scholar between 1900 and 2016 for all injury severity indices. The review yielded only indices that were focused on anatomical and physiological profiles derived from clinical and facility-based data. ${ }^{15162021}$ These anatomical and physiological profiles overlapped descriptions from the body functions and structures domain of the WHO ICF conceptual model, and do not include other primary domains such as the activity and participation domains. Hence, we created indicators for the anatomical and physiological profiles, similar to indices derived from the clinical and facilitybased data, and went further to describe indicators that capture activity and participation following an injury event from a population-level perspective using questionnaires adapted to the WHO Injury Surveillance Guideline and ICF index. We propose a comprehensive set of eight indicators for constructing the PISA score. These indicators cover the body structures and functions domain: (1) anatomical and (2) physiological profiles related to non-fatal injuries; activity and treatment domain: (3) postinjury immobility, (4) posinjury hospitalisation, (5) surgical treatment and (6) extent of postinjury disability and participation domain: (7) number of days for which an individual required assisted living for routine tasks (eg, bathing) following the injury event, and (8) number of days lost at work or school. We added a treatment component to the activity domain given that treatment may directly modify the extent of activity following an injury event, and conceptualised the personal and environmental factors of the WHO ICF conceptual model as determinants of injury severity, that is, they may

\begin{tabular}{|c|c|}
\hline Indicator & Definition \\
\hline $\begin{array}{l}\text { Anatomical } \\
\text { profile }\end{array}$ & $\begin{array}{l}\text { Presence of fractures, dislocation or } \\
\text { internal injuries involving any anatomical } \\
\text { parts (including head, neck, chest, } \\
\text { abdomen, upper limbs, hands, waist, lower } \\
\text { limbs, and/or foot) following the injury } \\
\text { event (yes/no). }\end{array}$ \\
\hline $\begin{array}{l}\text { Physiological } \\
\text { profile }\end{array}$ & $\begin{array}{l}\text { Presence of loss of consciousness just } \\
\text { after the injury event (yes/no). }\end{array}$ \\
\hline $\begin{array}{l}\text { Postinjury } \\
\text { immobility }\end{array}$ & $\begin{array}{l}\text { If injured individual was unable to walk } \\
\text { away unassisted from the injury site (yes/ } \\
\text { no). }\end{array}$ \\
\hline $\begin{array}{l}\text { Postinjury } \\
\text { hospitalisation }\end{array}$ & $\begin{array}{l}\text { If injured individual was admitted for } \\
\text { treatment at a hospital or health facility } \\
\text { following the injury event (yes/no). }\end{array}$ \\
\hline $\begin{array}{l}\text { Surgical } \\
\text { intervention }\end{array}$ & $\begin{array}{l}\text { If any surgical operation was done to treat } \\
\text { the injured individual at the hospital (yes/ } \\
\text { no). }\end{array}$ \\
\hline $\begin{array}{l}\text { Postinjury } \\
\text { disability }\end{array}$ & $\begin{array}{l}\text { If there was any permanent loss of } \\
\text { functionality in at least one of vision, } \\
\text { hearing, mobility, activity with hands, } \\
\text { speech or intellect following the injury } \\
\text { event (yes/no). }\end{array}$ \\
\hline $\begin{array}{l}\text { Duration of } \\
\text { assisted living } \\
\text { for routine tasks }\end{array}$ & $\begin{array}{l}\text { The no of days for which the injured } \\
\text { individuals required assistance with } \\
\text { activities of daily living following the injury } \\
\text { event, including walking, sitting/getting out } \\
\text { of bed, climbing stairs, bathing, or toileting } \\
\text { (values greater than } 30 \text { days vs } 30 \text { days or } \\
\text { less). }\end{array}$ \\
\hline $\begin{array}{l}\text { Days lost from } \\
\text { work or school }\end{array}$ & $\begin{array}{l}\text { The no of days for which the injured was } \\
\text { not able to go to work or school following } \\
\text { the injury event (values greater than } 6 \text { days } \\
\text { vs } 6 \text { days or less). }\end{array}$ \\
\hline
\end{tabular}

PISA, Population-based Injury Severity Assessment.

differentially explain how injury severity is experienced and the level of injury severity that is experienced. ${ }^{1922}$

The eight indicators were assessed for all non-fatal injury events recorded in the census $(n=119703)$, from 104737 individuals. ${ }^{5}$ The frequency and distribution of each indicator was explored for each non-fatal injury event, and the indicators were further classified into binary variables (table 1). Injuries with impairments (problems in body function or structure such as a significant deviation (eg, fracture, internal haemorrhage) or loss (eg, loss of consciousness) that may require skill and intensive medical/surgical management were classified as severe following the guidelines from WHO Injury Surveillance guidelines. ${ }^{1719}$ Hence, binary variables were created based on the presence of fractures, dislocation or internal injuries (yes/no) for the anatomical profile indicator, and loss of consciousness (yes/no) for the physiological profile indicator. Any head injury with associated loss of consciousness was categorised as a 'yes' for the anatomical profile. For the postinjury immobility, postinjury 
hospitalisation and surgical intervention indicators, these were classified as binary variables based on a yes/ no response regarding the presence of these indicators immediately following the injury event. The postinjury disability indicator was classified as a binary variable based on the presence (yes/no) of any permanent loss of functionality in at least one of vision, hearing, mobility, activity with hands, speech and intellect following the injury event. The duration of assisted living for routine tasks and days lost from work or school indicators were classified as binary variables with reference to the population standards, consistent with the recommended approach for calibrating performance problem under the activity and participation domains of the WHO ICF index, that is, classification of performance is based on the distribution of the performance variable in the population. ${ }^{23}$ Hence the variables for both indicators were divided into quartiles, and the median and IQR (range of the middle 50\% of the dataset) of the variable distribution was considered as a measure of central tendency and dispersion for the data distribution given that both variables were positively skewed. For the duration of assisted living with routine tasks indicator, the median duration and IQR in days were the same (ie, 30 days or less), and this value was used as a cut-off for classifying the indicator into a binary variable (ie, values greater than 30 days vs 30 days or less) assuming that the dataset $(n=119703$ events from 104737 individuals) is representative of the population. For the days lost from work or school indicator, the median duration and IQR were different (the median was 4 days and IQR was 6 days). Hence, the IQR (ie, 6 days), the measure of dispersion was preferred given the positive skeweness of the dataset and was used as a cut-off for classifying the indicator into a binary variable (ie, values greater than 6 days vs 6 days or less). The histograms for duration of assisted living and days lost from work or school variables are included in online supplemental figures 1-6.

\section{Developing an injury severity index}

A principal component analysis (PCA) was applied to summarise the eight indicators into a single index of injury severity. ${ }^{24} 25$ First, the correlation matrix of the eight indicators was assessed for all non-fatal injury events in the census ( $\mathrm{n}=119703)$, (online supplemental table 1$)$. Second, the Kaiser-Meyer-Olkin (KMO) test and Bartlett's test of sphericity was conducted to assess the suitability of the dataset for factor analysis by measuring the proportion of the total variance among the eight indicators that might be common variance. A KMO value $>0.6$ suggests that the sample is adequate, and Bartlett's test with $\mathrm{p}<0.05$ suggests that the partial correlation among the indicators is low and that the indicators are largely uncorrelated. Third, a principal component factor method was used to analyse the correlation matrix for the eight indicators and to decompose the eigenvalues (variance of each latent factor represented by each indicator) without restricting the number of factors that should be retained in the dataset. There was one factor with eigenvalue $>1$ (which accounted for $97 \%$ of the variance in the dataset) in this initial factor solution, and this single factor was defined as 'injury severity' (see online supplemental table 2 for the factor solution). ${ }^{24}{ }^{25}$ Fifth, a PCA was performed and constricted to a single factor to explain the proportion of variance in each of the eight indicator variables accounted for by the single factor (ie, injury severity). The proportion of variance (ie, eigenvector or principal component loading for each indicator in a single component PCA) was then used as weights to estimate the ISS (called the PISA score) for each injury event as shown:

\section{PISA Index Score $_{\mathrm{i}}=\mathrm{S}_{\mathrm{ij}} \bullet \mathrm{L}_{\mathrm{j}}$}

where $S_{i j}$ is the standardised mean of the injury severity indicator variable (j) for injury event (i), and $\mathrm{L}_{\mathrm{j}}$ is the proportion of variance (eigenvector or principal component loading) in the injury severity indicator variable (j) explained by the single factor. The PISA index scores for all recorded non-fatal injury events $(n=119703)$ were estimated and categorised into tertiles corresponding to low, moderate and high severity tertiles.

\section{Validation of the injury severity index}

To validate the PISA index score, the principal component loadings (or eigenvectors) for the injury severity indicators estimated from the non-fatal injury data were used to compute injury severity index scores for all fatal injuries in the SoLiD census dataset $(n=449)$ by multiplying the corresponding eigenvectors with the standardised mean for three of the injury severity indicators (anatomical profile, physiological profile and postinjury hospitalisation) in the fatal injury data. Other injury severity indicators (such as any postinjury disability, loss of school/work days, duration of assisted living and immobility) were not relevant for fatal injury outcomes. The cut-offs for classifying the PISA index scores for the non-fatal injuries into severity tertiles were then applied to the PISA index scores for the fatal injuries to determine the criterion validity of the PISA index by observing what proportion of fatal injuries will be classified as high, moderate or low severity. This validation analysis assumed that fatal injuries are highly severe since they resulted in death.

\section{Exploring the determinants of injury severity for non-fatal injuries}

Using the validated PISA index score, we explored the determinants of the injury severity categories (low, medium and high injury severity) for all non-fatal injury events for population in rural Bangladesh using the SoLiD census dataset. First, we performed a crosstabulation between each external cause of injury and injury severity categories to observe injury severity by external causes from a population-based perspective. The WHO ICF model for health and disability conceptualises personal (eg, gender, age) and environmental factors (eg, socioeconomic factor, physical terrain) as factors that could influence the level of injury severity. Using bivariate and multivariate ordered logistic regression models, we explored these personal factors (age, gender, occupation, educational level) and environmental factors (household 
socioeconomic index, subdistrict and study site variables (as a proxy for the physical terrain)) as determinants of injury severity. Furthermore, we explored injury characteristics (intention of injury, eg, unintentional, intentional/self-harm and external cause of injuries, for example, road traffic, drowning, burn, fall, cut) as additional determinants of injury severity as studies from HIC settings have suggested that these injury characteristics may determine the severity of injuries presenting at the facility-level. ${ }^{26}{ }^{27}$ The household socioeconomic index was calculated using a PCA on information about ownership of household durable assets (eg, television), housing characteristics (eg, roofing material) and access to utilities and infrastructure (eg, electricity, toilet and potable water). ${ }^{25} 28$

The SEs for the OR in the ordered logistic regression model were adjusted for the clustering effect of multiple injury events on an individual by using the HuberWhite sandwich estimator. Complete-case analyses were performed for estimating the model for the PISA index score and injury severity determinants. All analyses were conducted in Stata statistical software 2015: Release V.14. ${ }^{29}$

\section{Assumptions}

The PCA is a non-parametric statistic. Hence, estimates arising from this model are independent of any hypothesis about data distribution. The ordered logistic regression assumes that the OR comparing non-fatal injury of medium severity with low severity is the same as the OR comparing high severity with medium severity.

\section{Patient and public involvement}

Local collaborators, including community, local and national level governments and researchers in Bangladesh were included in several discussions to identify needs and gaps in injury surveillance, and to develop the survey tools, measurements and study protocols. The questionnaire underwent multiple revisions based on feedback from these meetings. Household heads were interviewed as participants in this study. No clinical patients were enrolled.

\section{RESULTS}

\section{Non-fatal injuries in rural Bangladesh}

The data source for this study was a population-based census of 270387 households and 1.16 million people from 451 villages in 51 unions from seven rural subdistricts (Matlab North, Matlab South, Daudkandi, Chandpur Sadar, Manohardi, Raiganj and Sherpur) in Bangladesh. These subdistricts capture different environmental conditions, that is, geographies and physical terrain, for injuries in rural Bangladesh. There were 104737 individuals who reported at least one injury event over a 6 months recall period, and $87.5 \%$ of these individuals reported only a single injury event during this period (online supplemental table 3).
Table 2 Indicators of injury severity in rural Bangladesh

\begin{tabular}{ll}
\hline Injury severity indicator & Percent severe $\mathbf{( 9 5 \% ~ C l )}$ \\
\hline & N events $=119703$ \\
& $N$ individuals $=104737$
\end{tabular}

Anatomical profile*

Fracture, dislocation and/or internal 10.67 (10.49 to 10.84) injury (yes)

\begin{tabular}{|c|c|}
\hline Upper limbs ( $n=72763)$ & $1.57(1.48$ to 1.67$)$ \\
\hline Hands $(n=87563)$ & 3.21 (3.09 to 3.33 ) \\
\hline Lower limbs $(n=81044)$ & $1.77(1.68$ to 1.87$)$ \\
\hline Foot $(n=79050)$ & 0.73 (0.68 to 0.80$)$ \\
\hline Waist (n=72689) & $1.53(1.44$ to 1.62$)$ \\
\hline Head $(n=72880)$ & $6.89(6.71$ to 7.08$)$ \\
\hline Neck ( $n=70992)$ & 6.61 (6.43 to 6.79$)$ \\
\hline Chest $(n=72459)$ & $1.51(1.42$ to 1.60$)$ \\
\hline Abdomen $(n=70753)$ & $0.21(0.18$ to 0.24$)$ \\
\hline \multicolumn{2}{|l|}{ Physiological profile } \\
\hline Unconscious state (yes) & $5.66(5.52$ to 5.79$)$ \\
\hline \multicolumn{2}{|l|}{ Postinjury hospitalisation } \\
\hline Yes & $2.22(2.14$ to 2.31$)$ \\
\hline \multicolumn{2}{|l|}{ Postinjury immobility } \\
\hline Yes & 3.84 (3.73 to 3.95$)$ \\
\hline \multicolumn{2}{|l|}{ Postinjury surgical treatment } \\
\hline Yes & 0.55 (0.50 to 0.59$)$ \\
\hline \multicolumn{2}{|l|}{ Postinjury disability } \\
\hline $\begin{array}{l}\text { At least one area of functionality } \\
\text { (eg, loss of vision, hearing, mobility, } \\
\text { activity with hands, speech, or } \\
\text { intellect) }\end{array}$ & $0.33(0.30$ to 0.36$)$ \\
\hline \multicolumn{2}{|l|}{ Duration of assisted living $>30$ days } \\
\hline $\begin{array}{l}\text { At least one area of functionality } \\
\text { (eg, assistance with activities of } \\
\text { daily living following the injury event, } \\
\text { including walking, sitting/getting out } \\
\text { of bed, climbing stairs, bathing, or } \\
\text { toileting) }\end{array}$ & 2.27 (2.18 to 2.35$)$ \\
\hline \multicolumn{2}{|l|}{ Loss of days at work/school $>6$ days } \\
\hline Loss of days $>6$ days & 29.0 (28.7 to 29.3$)$ \\
\hline
\end{tabular}

*Injuries sustained on different body parts were treated as isolated injuries for any injury event involving more than one body part (polytrauma), $7 \%$ of injury events reported involved more than one body part.

\section{Injury severity indicators based on non-fatal injury data}

Eleven per cent of all injury events involved fracture, dislocation or internal injury of body parts, $6 \%$ were associated with loss of consciousness, $2 \%$ required assistance with activities of daily living greater than 30 days and less than $1 \%$ required surgical intervention or was associated with permanent disability (eg, loss of vision, hearing) (table 2).

Based on the definition of injury severity using the anatomical profile, injuries involving the head were the most severe followed by neck injuries, $6.9 \%$ and $6.6 \%$, 
Table 3 Principal component loadings for the Injury Severity Index

\begin{tabular}{ll}
\hline Injury severity indicator variable & $\begin{array}{l}\text { Principal component } \\
\text { loading or eigenvector }\end{array}$ \\
\hline Anatomical profile & 0.47 \\
\hline Physiological profile & 0.44 \\
\hline Postinjury hospitalisation & 0.43 \\
\hline Postinjury immobility & 0.07 \\
\hline Postinjury surgical treatment & 0.36 \\
\hline Postinjury disability & 0.17 \\
\hline Duration of assisted living $>30$ days & 0.34 \\
\hline Loss of days at work/school $>6$ days & 0.34 \\
\hline
\end{tabular}

respectively. Injuries involving the abdomen and foot were the least severe, $0.2 \%$ and $0.7 \%$, respectively.

\section{Injury severity index for non-fatal injuries}

The KMO and Bartlett's tests were 0.638 and $<0.001$, respectively, for the eight injury severity indicator variables suggesting that the data is adequate for factor analysis and that the partial correlation among these variables is low (see online supplemental table 1 for the correlation matrix). The initial factor solution for the correlation matrix (without restricting the number of factors that should be retained in the dataset) yielded one factor with eigenvalue $>1$ which accounted for $97 \%$ of the variance in the dataset (see online supplemental table 2 for the factor solution, online supplemental figure 7. for the scree plot). The subsequent PCA on the eight injury severity indicator variables restricted to the single factor, called 'injury severity', suggests that the injury severity factor accounted for most of the variance in each of the variables, over $30 \%$ for all the indicator variables except postinjury immobility and postinjury disability. Table 3 shows the eigenvectors or principal component loadings associated with each variable.

The principal component loadings were used to estimate the PISA index score as described previously. Based on the PISA index score, most injury events (64\%) were categorised as low severity, while $14 \%$ were highly severe in nature (table 4). Using the principal component loadings or eigenvectors and score cut-offs from the non-fatal injury data, $82 \%$ of all fatal injuries $(n=449)$ were categorised as highly severe, while $13 \%$ were categorised as injury events of low severity which suggest that the PISA index accurately predicted severe injuries in over 8 out of 10 events, and that the criterion validity of index is high in predicting injury severity (table 5 ).

\section{Injury Severity Index by external causes of non-fatal injury}

Whereas falls $(38.56 \%)$, cuts $(22.2 \%)$ and injuries by blunt object $(9.83 \%)$ were the most common external causes of non-fatal injuries, they were mostly categorised as less severe; $61 \%, 74 \%$ and $66 \%$ for falls, cuts and injury by blunt objects, respectively (table 4 ).

Attempted suicide $(0.05 \%)$ and unintentional poisoning $(0.07 \%)$ were the least reported external causes of nonfatal injuries; however, these were mostly categorised as highly severe injuries according to the PISA index, 52\% and $57 \%$ respectively. Other external causes of non-fatal injuries that were frequently categorised as highly severe

Table 4 Injury severity categories for non-fatal injuries by external causes in rural Bangladesh

\begin{tabular}{lllll}
\hline & & \multicolumn{3}{l}{ \% injury severity } \\
\cline { 3 - 5 } External causes of injuries & No of injury events (\% of total) & Low & Moderate & High \\
\hline All injuries & 119703 & 64.43 & 21.22 & 14.35 \\
\hline Fall & $44502(38.56)$ & 60.49 & 21.19 & 18.32 \\
\hline Cut injury & $25618(22.2)$ & 73.7 & 20.68 & 5.62 \\
\hline Injury by blunt object & $11350(9.83)$ & 66.3 & 23.15 & 10.56 \\
\hline Road transport injury & $10145(8.79)$ & 48.75 & 28.57 & 22.68 \\
\hline Animal bite injury & $8680(7.52)$ & 80.29 & 13.11 & 6.6 \\
\hline Burn & $6119(5.30)$ & 69.29 & 23.55 & 7.16 \\
\hline Drowning & $3334(2.89)$ & 62.81 & 14.07 & 23.13 \\
Violence & $3272(2.83)$ & 44.28 & 20.54 & 35.18 \\
\hline Machine injury & $1253(1.09)$ & 55.55 & 28.73 & 15.72 \\
\hline Electrocution & $836(0.72)$ & 58.25 & 14.11 & 27.63 \\
\hline Suffocation & $175(0.15)$ & 64.57 & 12 & 23.43 \\
\hline Unintentional poisoning & $77(0.07)$ & 25.97 & 16.88 & 57.14 \\
\hline Attempted suicide & $56(0.05)$ & 39.29 & 8.93 & 51.79 \\
\hline Others & $2(0)$ & 50 & 50 & 0 \\
\hline
\end{tabular}

${ }^{*} 13.6 \%$ ( ${ }^{*} 13.6 \%(n=4284)$ of injury events missing information on external causes; hence, number of injury events used for the frequency was $\mathrm{n}=115419$. 
Table 5 Injury severity categories for fatal injuries in rural Bangladesh

\begin{tabular}{llcc}
\hline $\begin{array}{l}\text { Injury } \\
\text { severity } \\
\text { categories }\end{array}$ & $\begin{array}{l}\text { PISA index score } \\
\text { cut-off }\end{array}$ & N (n=449) & $\begin{array}{l}\text { Per } \\
\text { cent }\end{array}$ \\
\hline Low severity & $\begin{array}{l}\text { Less than or equals to } \\
-0.650\end{array}$ & 57 & 12.69 \\
$\begin{array}{l}\text { Moderate } \\
\text { severity }\end{array}$ & $\begin{array}{l}\text { Greater than }-0.650 \text { but } \\
\text { less than or equals to } \\
\text {-0.299 }\end{array}$ & 26 & 5.79 \\
High severity & Greater than -0.299 & 366 & 81.51 \\
\hline
\end{tabular}

PISA, Population-basedlnjury Severity Assessment.

include violence $(35 \%)$, electrocution (28\%), suffocation (23\%), drowning (23\%) and RTIs.

\section{Sociodemographic factors and other determinants of injury severity}

Online supplemental table 4 shows the frequency for all the determinants of injury severity explored in the regression analysis. In the adjusted analyses, the odds of higher injury severity were significantly higher with male compared with female (OR 1.16, 95\% CI 1.12 to 1.21); elderly $\geq 65$ years compared with adults $25-64$ years (OR $1.30,95 \%$ CI [1.23 to 1.36); and in lower and lowest socioeconomic groups compared with the highest socioeconomic groups (table 6).

A statistically significant dose-response relationship was observed between injury severity and age for those aged 10 years and above, that is, the odds of higher injury severity increase with age. Similarly, educational status was protective of injury severity with a dose-response relationship, that is, compared with those without any education, the ORs of higher injury severity for those with primary, secondary and postsecondary education were $0.96(0.93$, $0.99), 0.84(0.81,0.88)$ and $0.82(0.76,0.88)$, respectively.

Odds of higher injury severity were associated with intentional injuries (intentional self-harm or assault inflicted by others) compared with unintentional injuries. With respect to external causes of injury, unintentional poisoning (OR 3.76, 95\% CI 2.30 to 6.16), attempted suicide (OR 2.02, 95\% CI 1.02 to 3.97) and violence (OR $1.21,95 \%$ CI 1.05 to 1.39 ) had increased odds of higher injury severity compared with RTIs, while other causes were associated with decreased odds (table 5).

Injury events from Chandpur Sadar subdistrict compared with Matlab North subdistrict, and in International Centre for Diarrhoeal Disease Research Bangladesh (ICDDRB) study site compared with Center for Injury Prevention and Research Bangladesh (CIPRB) study site were also associated with increased odds of highly severe injuries which suggest that environmental factors are a major determinants of injury severity. Whereas most of rural Bangladesh is a low lying area, areas covered by the ICDDRB study site and Chandpur Sadar subdistrict are right on the tributaries of Meghna and Padma rivers, two major rivers in Bangladesh, and are exceptionally prone to flooding.

\section{DISCUSSION}

Unlike other indices of injury severity assessment, which are derived from facility-based or clinical data, this study describes a systematic approach for injury severity assessment using population-based data. ${ }^{5}$ The study presents relevant injury severity indicators and statistical weights for estimating injury severity index scores, PISA index scores, that could be applied by non-clinicians to retrospectively assess injury severity at the population level. The PISA index has high criterion validity to predict highly severe injuries and injury mortality. The study also illustrates the utility of the index by presenting the determinants of severe injuries in rural Bangladesh from a population-based perspective.

The injury severity indicators for the PISA index are based on the WHO ICF model of health and disability and include indicators that capture body structures and functions, activity and participation domains of the ICF model operationalised for data collected outside of clinical settings, and further expanded to include a treatment domain, for example, indicators of postinjury hospitalisation and surgical treatment as measures of injury severity. There are many different scoring systems available for measuring injury severity such as TRISS, ASCOT, GCS, Acute Physiology and Chronic Health Evaluation, Kampala Trauma Score (KTS) among others. ${ }^{14} 1630$ All of these scoring systems are only applicable in clinical and facility-based settings to hospital-based injury surveillance data, and none can be applied to population-based data. Like these other systems, the PISA index indicators captures descriptors of anatomical and physiological profiles but adapted for population-based survey, and with the added benefit of including others indicators of injury severity (eg, postinjury disability, loss of work/ school days, assisted living) that can be collected outside of clinical settings. The PISA index was able to accurately predict fatal injuries in $82 \%$ of cases, which was higher compared with the TRISS, ASCOT and KTS predictive ability reported in the literature. ${ }^{30} 31$ Furthermore, the PISA index includes all indicators of the the KTS, developed to account for limited data and resources in low resource settings, such as body part injured, vital signs and neurological status in addition to information available from community settings such as postinjury disability and days of assisted living. Similar to the ASCOT, which is prioritised over other indices for its more accurate description of anatomic injuries, the PISA index identified head injury as the most severe forms of injury. ${ }^{10}$

Based on the PISA index, intentional injuries and most unintentional poisoning, attempted suicides and violence were highly severe in nature, despite having some of the lowest prevalence among external injury causes. ${ }^{32}$ Unlike other injury severity indices, the PISA index has the ability to predict severity of external causes of injuries and 
Open access

Table 6 Determinants of injury severity among populations in rural Bangladesh

\begin{tabular}{|c|c|c|c|c|}
\hline Variable & $\begin{array}{l}\text { Unadjusted OR of } \\
\text { injury severity }\end{array}$ & $95 \% \mathrm{Cl}$ & $\begin{array}{l}\text { Adjusted OR of } \\
\text { injury severity }\end{array}$ & $95 \% \mathrm{Cl}$ \\
\hline & \multicolumn{2}{|c|}{$\mathrm{n}$ events $=115301 \mathrm{n}$ cluster $=101812$} & \multicolumn{2}{|c|}{$n$ events $=115301 \mathrm{n}$ cluster $=101812$} \\
\hline \multicolumn{5}{|l|}{ Sex } \\
\hline Male & 1.15 & $(1.12 \text { to } 1.18)^{\star \star \star}$ & 1.16 & $(1.12 \text { to } 1.21)^{\star \star \star}$ \\
\hline Reference:female & 1.00 & & 1.00 & \\
\hline \multicolumn{5}{|l|}{ Age } \\
\hline$<1$ year & 1.21 & $(1.02 \text { to } 1.44)^{\star}$ & 1.07 & (0.87 to 1.32$)$ \\
\hline $1-4$ years & 1.01 & (0.97 to 1.06$)$ & 0.88 & $(0.78 \text { to } 1.00)^{*}$ \\
\hline $5-9$ years & 0.99 & (0.95 to 1.04$)$ & 1.00 & 90.92 to 1.08$)$ \\
\hline $10-14$ years & 0.85 & $(0.82 \text { to } 0.89)^{\star \star \star}$ & 0.89 & $(0.82 \text { to } 0.96)^{\star \star}$ \\
\hline $15-17$ years & 0.88 & $(0.83 \text { to } 0.94)^{\star \star \star}$ & 0.89 & $(0.82 \text { to } 0.97)^{\star *}$ \\
\hline 18-24years & 0.89 & $(0.85 \text { to } 0.93)^{\star \star \star}$ & 0.91 & 0.87 to 0.96$)^{\star \star \star}$ \\
\hline $65+$ & 1.39 & $(1.32 \text { to } 1.46)^{\star \star \star}$ & 1.30 & $(1.23 \text { to } 1.36)^{\star \star \star}$ \\
\hline Reference: $25-64$ years & 1.00 & & 1.00 & \\
\hline \multicolumn{5}{|l|}{ Occupation } \\
\hline Business & 1.15 & $(1.08 \text { to } 1.23)^{\star \star \star}$ & 1.00 & (0.94 to 1.07$)$ \\
\hline Skilled labour (professional) & 1.15 & $(1.09 \text { to } 1.21)^{\star \star \star}$ & 1.06 & $(1.00 \text { to } 1.13)^{\star}$ \\
\hline Unskilled/domestic (unskilled) & 1.17 & $(1.08 \text { to } 1.26)^{\star \star \star}$ & 1.03 & (0.95 to 1.12$)$ \\
\hline Rickshaw/bus (transport worker) & 1.39 & $(1.28 \text { to } 1.51)^{\star \star \star}$ & 0.95 & (0.87 to 1.03$)$ \\
\hline Students & 0.92 & $(0.88 \text { to } 0.96)^{\star \star \star}$ & 0.98 & (0.90 to 1.06$)$ \\
\hline Retired/unemployed/housewife & 1.00 & (0.96 to 1.05$)$ & 0.98 & (0.93 to 1.04$)$ \\
\hline Not applicable (children) & 1.06 & $(1.01 \text { to } 1.12)^{*}$ & 1.06 & (0.94 to 1.19$)$ \\
\hline Not applicable (others) & 1.35 & $(1.08 \text { to } 1.68)^{\star \star}$ & 1.45 & $(1.16 \text { to } 1.82)^{\star \star}$ \\
\hline Reference: agriculture/farming & 1.00 & & 1.00 & \\
\hline \multicolumn{5}{|l|}{ Educational level } \\
\hline Primary & 0.96 & $(0.94 \text { to } 1.00)^{\star}$ & 0.96 & $(0.93 \text { to } 0.99)^{\star}$ \\
\hline Secondary & 0.87 & $(0.84 \text { to } 0.90)^{\star \star \star}$ & 0.84 & $(0.81 \text { to } 0.88)^{\star \star \star}$ \\
\hline $\begin{array}{l}\text { Postsecondary (alevel, college, } \\
\text { advanced degree) }\end{array}$ & 0.91 & $(0.85 \text { to } 0.97)^{\star \star}$ & 0.82 & $(0.76 \text { to } 0.88)^{\star \star \star}$ \\
\hline Reference: no education & 1.00 & & 1.00 & \\
\hline \multicolumn{5}{|l|}{ Socioeconomic status } \\
\hline Higher & 1.03 & (0.99 to 1.07$)$ & 1.05 & $(1.00 \text { to } 1.09)^{\star}$ \\
\hline Middle & 1.01 & (0.97 to 1.05$)$ & 1.02 & (0.97 to 1.06$)$ \\
\hline Lower & 1.00 & (0.96 to 1.04$)$ & 1.06 & $(1.01 \text { to } 1.10)^{\star}$ \\
\hline Lowest & 1.02 & (0.98 to 1.06$)$ & 1.07 & $(1.02 \text { to } 1.12)^{\star \star}$ \\
\hline Reference: highest & 1.00 & & 1.00 & \\
\hline \multicolumn{5}{|l|}{ Study site } \\
\hline ICDDRB & 1.51 & $(1.47 \text { to } 1.55)^{\star \star \star}$ & 1.33 & $(1.28 \text { to } 1.40)^{\star \star *}$ \\
\hline Reference: CIPRB & 1.00 & & 1.00 & \\
\hline \multicolumn{5}{|l|}{ Subdistrict } \\
\hline Matlab South & 0.85 & $(0.82 \text { to } 0.88)^{\star \star \star *}$ & 0.83 & $(0.80 \text { to } 0.86)^{\star \star \star}$ \\
\hline Chandpur Sadar & 1.53 & $(1.46 \text { to } 1.59)^{\star \star \star}$ & 1.49 & $(1.43 \text { to } 1.56)^{\star \star \star}$ \\
\hline Daud Kandi & 0.73 & $(0.68 \text { to } 0.78)^{\star \star \star}$ & 0.74 & $(0.69 \text { to } 0.79)^{\star \star \star}$ \\
\hline Raiganj & 0.59 & $(0.56 \text { to } 0.62)^{\star \star \star}$ & 0.83 & $(0.78 \text { to } 0.88)^{\star \star \star}$ \\
\hline Sherpur & 0.66 & $(0.63 \text { to } 0.69)^{\star \star \star}$ & 0.95 & (0.91 to 1.01 ) \\
\hline
\end{tabular}

Continued 
Table 6 Continued

\begin{tabular}{|c|c|c|c|c|}
\hline Variable & $\begin{array}{l}\text { Unadjusted OR of } \\
\text { injury severity }\end{array}$ & $95 \% \mathrm{Cl}$ & $\begin{array}{l}\text { Adjusted OR of } \\
\text { injury severity }\end{array}$ & $95 \% \mathrm{Cl}$ \\
\hline Manohardi & 0.70 & $(0.67 \text { to } 0.73)^{\star \star \star}$ & 1.00 & \\
\hline Reference: Matlab North & 1.00 & & 1.00 & \\
\hline \multicolumn{5}{|l|}{ Intention } \\
\hline Intentional self-harm & 2.34 & $(1.75 \text { to } 3.13)^{\star \star \star}$ & 1.48 & $(1.10 \text { to } 1.99)^{\star \star}$ \\
\hline Assault/violence by others & 2.74 & $(2.52 \text { to } 2.99)^{\star \star \star}$ & 1.20 & $(1.03 \text { to } 1.41)^{\star}$ \\
\hline $\begin{array}{l}\text { Undetermined (self-harm or } \\
\text { assault) }\end{array}$ & 2.95 & $(1.77 \text { to } 4.93)^{\star \star \star}$ & 2.17 & $(1.28 \text { to } 3.66)^{\star \star}$ \\
\hline Reference: Unintentional injury & 1.00 & & 1.00 & \\
\hline \multicolumn{5}{|l|}{ Injury mechanism } \\
\hline Attempted suicide & 2.48 & $(1.29 \text { to } 4.76)^{\star \star}$ & 2.02 & $(1.02 \text { to } 3.97)^{\star}$ \\
\hline Violence & 1.44 & $(1.33 \text { to } 1.56)^{\star \star \star}$ & 1.21 & $(1.05 \text { to } 1.39)^{\star \star}$ \\
\hline Fall & 0.65 & $(0.63 \text { to } 0.68)^{\star \star \star}$ & 0.63 & $(0.61 \text { to } 0.66)^{\star \star \star}$ \\
\hline Cut & 0.33 & $(0.31 \text { to } 0.34)^{\star \star \star}$ & 0.33 & $(0.32 \text { to } 0.35)^{\star \star \star}$ \\
\hline Burn & 0.40 & $(0.38 \text { to } 0.43)^{\star \star \star}$ & 0.45 & $(0.42 \text { to } 0.48)^{\star \star \star}$ \\
\hline Near drowning & 0.65 & $(0.60 \text { to } 0.72)^{\star \star \star}$ & 0.63 & $(0.57 \text { to } 0.70)^{\star \star \star}$ \\
\hline Poisoning & 3.84 & $(2.35 \text { to } 6.28)^{\star \star *}$ & 3.76 & $(2.30 \text { to } 6.16)^{\star \star \star}$ \\
\hline Machine & 0.73 & $(0.66 \text { to } 0.82)^{\star \star \star}$ & 0.73 & $(0.65 \text { to } 0.81)^{\star \star \star}$ \\
\hline Electrocution & 0.83 & $(0.70 \text { to } 0.97)^{\star}$ & 0.90 & (0.76 to 1.05$)$ \\
\hline Animal bite & 0.24 & $(0.22 \text { to } 0.25)^{\star \star \star}$ & 0.25 & $(0.24 \text { to } 0.27)^{\star \star \star}$ \\
\hline Blunt object & 0.47 & $(0.45 \text { to } 0.50)^{\star \star \star}$ & 0.46 & $(0.43 \text { to } 0.48)^{\star \star \star}$ \\
\hline Suffocation & 0.62 & $(0.41 \text { to } 0.94)^{*}$ & 0.60 & $(0.39 \text { to } 0.92)^{*}$ \\
\hline Others & 0.68 & (0.11 to 4.27 ) & 0.61 & (0.12 to 3.17$)$ \\
\hline Reference: RTI & 1.00 & & 1.00 & \\
\hline
\end{tabular}

${ }^{*} \mathrm{P}<0.05,{ }^{* *} \mathrm{p}<0.01,{ }^{* * *} \mathrm{p}<0.001$.

CIPRB, Center for Injury Prevention and Research Bangladesh; ICDDRB, International Centre for Diarrhoeal Disease Research Bangladesh; RTI, road traffic injuries.

severity based on the intention of the injury. Thus, the PISA index is useful for assessing the burden of injuries based on intention and external causes in communitybased settings, especially those where intentional injuries like suicide and violence are stigmatised and go unreported due to sociocultural and medico-legal reasons. For example, Bangladesh has high suicidal rates, especially among young married women, and these statistics are higher than global rates and comparable to other South Asian countries like India and Pakistan. ${ }^{5} 3233$ Intimate partner violence, domestic violence and lower socioeconomic status of women in these settings are some of the commonly cited reasons and are rarely addressed by evidence-based interventions due to stigma associated with them. ${ }^{33}$

Based also on the PISA index, some of the determinants of injury severity include gender, age, educational level, socioeconomic status, intention and the external causes of injuries. Males had higher prevalance and more severe injuries than females in the rural population of Bangladesh-likely due to increased risk-taking behaviour and environmental exposure to injury hazards among males. ${ }^{34}{ }^{35}$ Consistent with other studies, this study also suggested that injury severity decreases with increasing level of education and increases with lower socioeconomic status. ${ }^{35}$ The PISA index predicted higher severity for RTI compared with most other external injury causes except poisioning, attempted suicide and violence. ${ }^{35}$ Similar to findings from HIC, intentional injuries like self-harm and assault are generally more severe than unintentional injuries, ${ }^{26} 27$ and mental health and behavioural disorders, such as low self esteem and anxiety may underline these injury circumstances. ${ }^{36}$

The PISA index can be used to provide improved assessment of the burden of injuries, conduct research on comparative assessment of non-fatal injuries, and serve as a guide for resource allocation of targeted programmes in LMICs. For instance, the application of PISA index in rural Bangladesh points to the need for policies around distribution and safe packaging of medications and harmful substances given the severity of unintentional poisoning in the country. ${ }^{37}$

The PISA index is a first in its relevance for injury severity assessment at the population-level and can be aggregated 
for populations, unlike existing indices which are mostly relevant at the individual level. As the index was developed using anatomical and physiological profiles, which are included in most individual-level indices, the PISA index could also be used to predict injury outcomes at the individual level. ${ }^{38} 39$ The validation showed that the PISA index was able to accurately classify $82 \%$ of injuries that resulted in a fatal outcome as highly severe. The index has a relatively simple scale based on summation of eight binary indicators, and could still yield robust estimates when reduced to three indicators (anatomical, physiological profiles and postinjury hospitalisation).

\section{Limitations}

The data source was based in rural Bangladesh, and may not be generalisable to other settings, especially HICs. The PISA index may require repeated use in other settings to be universally applicable. Information and recall biases could have also affected the findings given that key information was retrospectively assessed over a 6-month and 1-year recall periods for non-fatal and fatal injury events, respectively. There may be differential recall of information on the indicators for the PISA index, and this has implications on the reliability and validity of the index; however, the combination of multiple indicators may have offset the impact of differential recall. Although an initial criterion validity was assessed for the PISA index, further validity assessments are still needed. The sensitivity and specificity of the PISA index could be further assessed, as well as the test-retest reliability, especially among LMIC populations outside of rural Bangladesh.

The PISA index is based on a nonparametric statistical procedure, the PCA, where no assumption is required regarding the underlying distribution of the data and this confers a methodological advantage; however, the results from such calculations, for example, the principal component loadings and eigenvectors, may be complicated to explain on their own, except when applied as used in the PISA index. The survey information required to operationalise the indicators for the PISA index are also quite extensive, and may not be readily accessible under small population-based study.

\section{Conclusion}

The PISA index, informed by existing injury severity indices and based on the WHO ICF conceptual model of health and disability, provides a valid and systematic approach for assessing injury severity at the population level, and is relevant for improving the characterisation of the burden and epidemiology of injuries in non-health facility-based settings. Like the TRISS, ASCOT and KTS indices, the PISA index is useful for assessing the personal and environmental determinants of injury severity, and highly predictive of injury mortality. Unlike those injury severity indices, the PISA index can facilitate the assessment of the burden of injuries based on intention, external causes and other factors in community-based settings. Additional testing of the PISA index is needed to further establish its validity and reliability for injury severity assessment, and for populations outside of rural Bangladesh.

\section{Author affiliations}

${ }^{1}$ Department of International Health, Johns Hopkins University Bloomberg School of Public Health, Baltimore, Maryland, USA

${ }^{2}$ Department of Occupational and Environmental Medicine, Yale School of Medicine, New Haven, Connecticut, USA

${ }^{3}$ Centre for Injury Prevention and Research Bangladesh, Dhaka, Bangladesh ${ }^{4}$ Maternal and Child Health Division, International Centre for Diarrhoeal Disease Research Bangladesh, Dhaka, Bangladesh

${ }^{5}$ Center on Commercial Determinants of Health, George Washington University Milken Institute of Public Health, Washington, District of Columbia, USA

Acknowledgements We would like to thank all the participants of the study who provided meaningful data and time to support the project activities, in addition to our field staff, data collectors, supervisors, creche mothers, assistants and data managers for their assistance with taking this project to fruition.

Contributors OA conceptualised, designed and analysed the data for the study as well coauthored the manuscript drafts. PA and KK coauthored the manuscript drafts. SM, DEMH and AAH provided technical feedback on the paper. All authors reviewed the final version of the manuscript.

Funding The study was funded by Bloomberg Philanthropies.

Competing interests None declared.

Patient consent for publication Not required.

Ethics approval Ethical approval for the larger study was taken from the Institutional Review Boards of the Johns Hopkins Bloomberg School of Public Health, International Centre for Diarrhoeal Disease Research, Bangladesh and Centre for Injury Prevention and Research, Bangladesh. (Ethical approval code: 00004746).

Provenance and peer review Not commissioned; externally peer reviewed.

Data availability statement No data are available. Data not available publicly.

Supplemental material This content has been supplied by the author(s). It has not been vetted by BMJ Publishing Group Limited (BMJ) and may not have been peer-reviewed. Any opinions or recommendations discussed are solely those of the author(s) and are not endorsed by BMJ. BMJ disclaims all liability and responsibility arising from any reliance placed on the content. Where the content includes any translated material, BMJ does not warrant the accuracy and reliability of the translations (including but not limited to local regulations, clinical guidelines, terminology, drug names and drug dosages), and is not responsible for any error and/or omissions arising from translation and adaptation or otherwise.

Open access This is an open access article distributed in accordance with the Creative Commons Attribution Non Commercial (CC BY-NC 4.0) license, which permits others to distribute, remix, adapt, build upon this work non-commercially, and license their derivative works on different terms, provided the original work is properly cited, appropriate credit is given, any changes made indicated, and the use is non-commercial. See: http://creativecommons.org/licenses/by-nc/4.0/.

\section{ORCID iDs}

Priyanka Agrawal http://orcid.org/0000-0003-1314-7143

Saidur Mashreky http://orcid.org/0000-0001-7892-798X

\section{REFERENCES}

1 World Health Organization. Injuries and violence: the facts 2014, 2014.

2 James SL, Castle CD, Dingels ZV, et al. Global injury morbidity and mortality from 1990 to 2017: results from the global burden of disease study 2017. Inj Prev 2020;26:i96-114.

3 Vos T, Lim SS, Abbafati C, et al. Global burden of 369 diseases and injuries in 204 countries and territories, 1990-2019: a systematic analysis for the global burden of disease study 2019. Lancet 2020;396:1204-22.

4 Ballesteros MF, Schieber R, Gilchrist J. Differential ranking of causes of fatal versus non-fatal injuries among US children. Inj Prev 2003;9:173-6. 
5 Alonge O, Agrawal P, Talab A, et al. Fatal and non-fatal injury outcomes: results from a purposively sampled census of seven rural subdistricts in Bangladesh. Lancet Glob Health 2017:5:e818-27.

6 Haagsma JA, van Beeck EF, Polinder S, et al. Novel empirical disability weights to assess the burden of non-fatal injury. Inj Prev 2008; $14: 5-10$

7 Farooq U, Nasrullah M, Bhatti JA, et al. Incidence of burns and factors associated with their hospitalisation in Rawalpindi, Pakistan. Burns 2011;37:535-40.

8 Puvanachandra P, Hoe C, El-Sayed HF, et al. Road traffic injuries and data systems in Egypt: addressing the challenges. Traffic Inj Prev 2012;13:44-56.

9 Hyder AA, He S, Zafar W, et al. One hundred injured patients a day: multicenter emergency room surveillance of trauma in Pakistan. Public Health 2017;148:88-95.

10 Champion HR, Copes WS, Sacco WJ, et al. Improved predictions from a severity characterization of trauma (ASCOT) over trauma and injury severity score (TRISS). J Trauma 1996;40:42-9.

11 Brenneman FD, Boulanger BR, McLellan BA, et al. Measuring injury severity: time for a change. J Trauma and Acute Care Surg 1998;44:580-2.

12 Naghavi M, Wang H, Lozano R. Global, regional, and national agesex specific all-cause and cause-specific mortality for 240 causes of death, 1990-2013: a systematic analysis for the global burden of disease study 2013. Lancet 2015;385:117-71.

13 Goris RJA. The injury severity score. World J Surg 1983;7:12-18.

14 Champion HR, Sacco WJ, Lepper RL, et al. An anatomic index of injury severity. J Trauma 1980;20:197-202.

15 Greenspan L, McLellan BA, Greig H. Abbreviated injury scale and injury severity score. J Trauma 1985;25:60-4.

16 Markle J, Cayten CG, Byrne DW, et al. Comparison between TRISS and ASCOT methods in controlling for injury severity. J Trauma 1992;33:326-32.

17 Holder Y, Peden M, Krug E. Injury surveillance guidelines. Geneva: World Health Organization, 2001.

18 Vyrostek SB, Annest JL, Ryan GW. Surveillance for fatal and nonfatal injuries - United States, 2001. MMWR Surveill Summ 2004;53:1-57.

19 World Health Organization. International classification of functioning, disability, and health: ICF. Geneva, 2001.

20 Kuhls DA, Malone DL, McCarter RJ, et al. Predictors of mortality in adult trauma patients: the physiologic trauma score is equivalent to the trauma and injury severity Score 11 No competing interests declared. J Am Coll Surg 2002;194:695-704.

21 Tempas JJ, Ramenofsky MAXL, Mollitt DL, et al. The pediatric trauma score as a predictor of injury severity: an objective assessment. J Trauma 1988;28:425-9.

22 Hulsbæk S, Larsen RF, Rosthøj S, et al. The Barthel index and the Cumulated ambulation score are superior to the de Morton mobility index for the early assessment of outcome in patients with a hip fracture admitted to an acute geriatric ward. Disabil Rehabil 2019;41:1351-9.

23 Body Functions. WHO ICF browser. Available: https://apps.who.int/ classifications/icfbrowser/

24 Jolliffe IT, Cadima J. Principal component analysis: a review and recent developments. philosophical transactions of the royal society A: mathematical, physical and engineering sciences 2016;374:20150202

25 Vyas S, Kumaranayake L. Constructing socio-economic status indices: how to use principal components analysis. Health Policy Plan 2006;21:459-68.

26 Saif S, Ibrahim Y, Bakhshayesh P. Higher risk of mortality in intentional traumatic injuries; a multivariate regression analysis of a trauma registry. Bull Emerg Trauma 2020;8:107.

27 Bakhshayesh P, Weidenhielm L, Enocson A. Factors affecting mortality and reoperations in high-energy pelvic fractures. Eur $J$ Orthop Surg Traumatol 2018;28:1273-82.

28 Filmer D, Pritchett LH. Estimating wealth effects without expenditure data-or tears: an application to educational enrollments in states of India. Demography 2001;38:115-32.

29 StataCorp. Stata statistical software: release 14. College Station, TX: StataCorp LP, 2015.

30 Weeks SR, Juillard CJ, Monono ME, et al. Is the Kampala trauma score an effective predictor of mortality in low-resource settings? A comparison of multiple trauma severity scores. World J Surg 2014;38:1905-11.

31 de Alencar Domingues C, Coimbra R, Poggetti RS, et al. New trauma and injury severity score (TRISS) adjustments for survival prediction. World J Emerg Surg 2018;13:1-6.

32 Johnston HB, Naved RT. Spousal violence in Bangladesh: a call for a public-health response. J Health, Popul and Nutr 2008:366-77.

33 Koenig MA, Ahmed S, Hossain MB, et al. Women's status and domestic violence in rural Bangladesh: individual- and communitylevel effects. Demography 2003;40:269-88.

34 Scholer SJ, Mitchel Jr EF, Ray WA. Predictors of injury mortality in early childhood. Pediatrics 1997;100:342-7.

35 Peden M, McGee K, Sharma G. The injury chart book: a graphical overview of the global burden of injuries. Geneva: World Health Organization, 20025.

36 Ellickson PL, McGuigan KA. Early predictors of adolescent violence. Am J Public Health 2000;90:566.

37 Soori H. Developmental risk factors for unintentional childhood poisoning. Saudi med J 2001;22:227-30.

38 Siegel JH, Rivkind Al, Dalal S. Early physiologic predictors of injury severity and death in blunt multiple trauma. Arch Surg 1990;125:498-508.

39 Thombs BD, Singh VA, Halonen J, et al. The effects of preexisting medical comorbidities on mortality and length of hospital stay in acute burn injury: evidence from a national sample of 31,338 adult patients. Ann Surg 2007;245:629. 